\title{
Investigation of the Balance and Attention of Dance Exercise
}

\author{
Gulsum Bastug $^{1 *}$, Yasemin Coşkun ${ }^{2}$, İlker Gunel ${ }^{3}$ \\ ${ }^{1}$ Muğla Sıtkı Koçman University, Faculty of Sports Science, Mugla/Turkey, \\ ${ }^{2}$ Muğla Sitkı Koçman Universities, Institute of Social Sciences, Mugla/Turkey \\ ${ }^{3}$ Usak University, Faculty of Sports Science, Usak/Turkey
}

DOI: $10.36348 /$ jaspe.2020.v03i03.001

| Received: 28.02.2019 | Accepted: 07.03.2020 | Published: 10.03.2020

*Corresponding author: Gulsum Bastug

Abstract

The purpose of this study is to examine the balance and attention characteristic of dance exercise. 200 university students with a mean age of $20.63+1.59$, who studied at the Faculty of Sport Sciences at Muğla Sitkı Koçman University in the 2016-2017 academic year participated in the study. University students participating in the study were taught 3 hours of Latin dance (salsa, bachata) once a week for 12 weeks. The "d2 attention test", which validity and reliability was performed in Turkish by Çağlar and Koruç [1], developed by Brickenkamp [2], was used to determine students' attention attributes related to dance exercise. Data analysis, frequency analysis, Impulsive statistics. Kolmokorov-Smirnov test, ttest, Mann-Whitney U test were used. As a result, there was no significant difference between the experimental and control groups of the body weight pretest and posttest values of the students participating in the research. A significant difference was found between the experimental and control groups in the balance posttest value. A positive change was determined in the attention, error, and concentration post-test values of the students who participated in the dance study. It has been determined that dance work positively affects balance and attentiveness.

Keywords: Attention, balance, body weight, concentration, dance, university students.

Copyright @ 2020: This is an open-access article distributed under the terms of the Creative Commons Attribution license which permits unrestricted use, distribution, and reproduction in any medium for non-commercial use (NonCommercial, or CC-BY-NC) provided the original author and source are credited.

\section{INTRODUCTION}

Dance defines it as an art branch where movement is the tool for feeling, understanding and communicating [3]. Dance; It is the presentation of the creative thinking power of the human with a motif on the body [4]. Dancing [5], which is a special expression of human motor behavior, is the art of expressing and expressing oneself to the outside of the individual with movements [6]. Dance, which includes sports, science and art, is the processing of the emotion presented in the moving body with a physiological development [7]. It is believed that dance contributes to healthy life as a physical activity, and has the potential to excite and motivate people. In addition, exercises that are not in the form of competition provide positive effects on emotional, mental and physical health [8]. It would not be wrong to see dance as a tool for both psychological and physiological relaxation and development. For whatever purpose, the activity contributes to development in different fields (cognitive, affective, psychomotor and social), primarily physical in human [9]. In addition to using dance as a tool that can express itself in human life; the contribution of dance to the human body as a sport has been the subject of many studies [10, 11]. Dance can increase perceived physical and mental well-being and social relationship as a multidimensional experience that includes emotional, physical, spiritual and social elements [12, 13]. The leading physical qualities for dance work are strength, flexibility, special endurance, and balance and body coordination [5]. Balance is a reflex provided by the central nervous system, where the organism's movement system functions in a static and dynamic manner. The system that provides the balance controls the body's position, position, direction, direction, direction or rotation in space [14]. Balance is the ability of the person to hold and maintain the center of gravity within the support surface [15]. Static equilibrium can be considered as an individual standing position while standing on one or both legs [16]. Dynamic balance is called the ability of the body to maintain its position during movement. Daily activities such as walking and running are controlled with dynamic balance [17]. Attention is the state of gathering emotions and thoughts on a topic, it can be defined as a targeted, conscious and intense perception [18]. The factors that affect attention; It is examined in two groups as stimulant and individual characteristics [19]. Features that are effective in choosing and focusing a stimulus; 
magnitude, violence, color, brightness, contrast, variability, repeat, movement, innovation, et al.[20-22]. Personal characteristics that affect attention are the expectations of the individual, the past life of the individual, the attention of the individual, the needs of the individual [19, 23-25]. Dance, which is included in the art in terms of movement and motor skills, and in the art with its visual and aesthetic aspects, is an application area that combines different disciplines. Physiological and psychological positive effects of dancing on the human body, their contribution to motor development are currently being investigated using scientific methods. It is believed that the person, who performs passive activities that move away from physical activity with the effect of developing technology, is different in terms of protecting physical and psychological health, apart from the usual athletes like dance. In the light of this information, the aim of the study is to examine the body composition, balance and attention values in dancing individuals.

\section{MATERIALS AND METHODS}

200 university students studying at the Muğla Sitkı Koçman University Faculty of Sport Sciences, 2016-2017 academic year, with an average age of 20.63 +1.59 , have voluntarily participated. University students participating in the study were taught 3 hours of Latin dance (salsa, bachata) once a week for 12 weeks. The control group did not take dance classes. The height, body weight, balance test, attention test of the students who took dance lessons (experimental group) and not (control group) were measured twice at the beginning and end of the study as pre-test and posttest. "D2 attention test", which was validated and validated in Turkish by Çağlar and Koruç [1], developed by Brickenkamp [2], was used to determine the attention characteristic of students regarding dance exercise. The study, in which balance and attention attribution related to dance exercise was examined, was conducted on students studying in Muğla Sitkı Koçman University Faculty of Sport Sciences. 100 university students who took dance lessons (experimental group) received 3 hours of Latin dance (salsa, bachata) lessons once a week for 12 weeks. The control group university students did not take dance classes. The height, body weight, balance test, attention test of the students who took dance lessons (dency group) and who did not take dance lessons (control group) were measured twice as pre-test post-test at the beginning and end of the study.

For balance and attention tests of students who do and do not do dance exercise; Balance (Flamingo Balance Test - FDT): The Flamingo Balance Test was used to determine the static balances of the research group. Static balance and reliability coefficient is 0.87 [26]. According to this test, the research group; $50 \mathrm{~cm}$ long, $4 \mathrm{~cm}$ height and $3 \mathrm{~cm}$ width he stands on balance by standing with a dominant foot on a wide balance device. He bends his other foot from the knee and pulls it towards his hip, holding it with his hand on the same side. While the research group is in such a balance with one foot, the time begins and tries to stay in balance for 1 minute. When the balance is disturbed (if he stops holding the foot, if he falls from the board, if he touches the ground with any part of his body, and so on), time is stopped. When the research subject mounts the balance device and restores his balance, the time continues from where it left off. The test continues in this way for a minute. When the time is up, it is counted as the number of times the subject has lost balance during the attempt to balance and this number is recorded as the balance score of the test at the end of the test. Flamingo static balance test should be applied twice with eyes open (GASD) and eyes closed (GKSD) twice, and the best value in both measurements should be recorded in seconds [27] d2 Attention Test.

The Turkish reliability and validity study of the $\mathrm{d} 2$ attention test developed by Brickenkamp in 1966 [28] was conducted by Çağlar and Koruç [1] the purpose of the test is to evaluate the constant attention and visual scanning ability [29]. The d2 Test is a measure of selective attention and mental concentration. In the handbook of the test, the structure of "attention and concentration" is performance-oriented, continuous, and used as a focus on choosing a stimulus [30]. Although the $\mathrm{d} 2$ Test was originally developed to distinguish drivers, it is currently used to assess attention in different fields (such as psychopharmacology, education, clinical, industry, and sports psychology) [30-31]. On the front page of the test, there is a section where the personal information and performance results of the subject will be recorded and a training line. There is a standard test form on the back page. The test page consists of 14 lines, each with 47 marked letters. There are 16 different letters in each line consisting of the letters "p" and "d" with one, two, three and four small signs. During the test, the subject has to scan the lines to ignore other unrelated letters, find the two signs "d" and draw the lines. The subject is given 20 seconds for each line. It can be applied individually or as a group [29-30]. The items marked in the $\mathrm{d} 2$ attention test were scored by reference to the $\mathrm{d} 2$ attention test studies of Çağlar and Koruç [1] \& Yayc1 [32], especially Toker, [33].

All data included in the study were classified according to the independent variables of the study and presented as mean and standard deviation. The normality distribution of the groups was examined with the Kolmokorov-Smirnov test. T-test for independent samples to compare normally distributed age, height and body weight variables, it was applied. MannWhitney $U$ test for independent groups and Wilcoxon test for dependent groups were used to compare variables that did not show normal distribution. Statistical calculations were made with SPSS 22.0 statistical package program and the statistical significance level was accepted as 0.05 . 


\section{FINDINGS}

Table-1: Descriptive information of the participants

\begin{tabular}{|c|c|c|c|c|c|}
\hline Variables & Groups & Gender & $\mathbf{N}$ & Average & SD \\
\hline \multirow[t]{6}{*}{ Age (Years) } & \multirow[t]{3}{*}{ Experiment } & Male & 63 & 20.86 & 1.51 \\
\hline & & Female & 37 & 20.24 & 1.67 \\
\hline & & Total & 100 & 20.63 & 1.59 \\
\hline & \multirow[t]{3}{*}{ Control } & Male & 62 & 20.56 & 2.42 \\
\hline & & Female & 38 & 20.13 & 1.86 \\
\hline & & Total & 100 & 20.40 & 2.22 \\
\hline \multirow[t]{6}{*}{ Height $(\mathrm{cm})$} & \multirow[t]{3}{*}{ Experiment } & Male & 63 & 173.78 & 6.98 \\
\hline & & Female & 37 & 162.84 & 4.70 \\
\hline & & Total & 100 & 169.73 & 8.17 \\
\hline & \multirow[t]{3}{*}{ Control } & Male & 62 & 172.97 & 5.68 \\
\hline & & Female & 38 & 162.89 & 5.73 \\
\hline & & Total & 100 & 169.14 & 7.50 \\
\hline \multirow[t]{6}{*}{ Weight (kg) } & \multirow[t]{3}{*}{ Experiment } & Male & 63 & 72.71 & 9.57 \\
\hline & & Female & 37 & 58.62 & 8.67 \\
\hline & & Total & 100 & 67.50 & 11.47 \\
\hline & \multirow[t]{3}{*}{ Control } & Male & 62 & 70.16 & 8.89 \\
\hline & & Female & 38 & 57.05 & 8.70 \\
\hline & & Total & 100 & 65.18 & 10.86 \\
\hline
\end{tabular}

Demographic information of the students participating in the research is given in Table 1 of 86
100 65.18. Prior to research. Experimental and control groups had similar age, height and body weight.

Table-2: Comparison of body weight and balance scores of the experiment and control group students

\begin{tabular}{|c|c|c|c|c|c|c|}
\hline Variables & Test & Group & Line Average & Line Total & $\mathbf{U}$ & $\boldsymbol{p}$ \\
\hline Body weight & \multirow{2}{*}{ Pretest } & Experimental & 105.72 & 10571.50 & 4478.500 & 0.202 \\
\cline { 3 - 6 } & & Control & 95.28 & 9528.50 & & \\
\cline { 3 - 6 } & \multirow{2}{*}{ Posttest } & Experimental & 105.92 & 10591.50 & 4458.500 & 0.186 \\
\cline { 3 - 6 } & & Control & 95.08 & 9508.50 & & \\
\hline \multirow{2}{*}{ Palance } & Pretest & Experimental & 104.76 & 10476.00 & 4574.000 & 0.295 \\
\cline { 3 - 6 } & & Control & 96.24 & 9624.00 & & \\
\cline { 3 - 7 } & Posttest & Experimental & 82.57 & 8174.50 & 3224.500 & \multirow{2}{*}{$0.000^{*}$} \\
\cline { 3 - 7 } & & Control & 117.26 & 11725.50 & & \\
\hline
\end{tabular}

As seen in Table 2 the comparison of the body weight and balance scores of the experimental and control group students participating in the study is presented. As a result of the comparison of the pretests. Experiment and control of body weight $(\mathrm{U}=4478.500)$ and balance scores $(\mathrm{U}=4574.000)$. It was determined that there was no difference between the groups ( $\mathrm{p}>$ 0.05). As a result of the comparison of the post tests. Body weight was similar between the experimental and control groups similar to the pre-test. It was determined that there was no difference between the groups ( $p$ >
0.05). As a result of comparing the posttests it was found that the weight of body did not differ significantly between the experimental and control groups similar to the pretest $(\mathrm{U}=4458.500 ; \mathrm{p}>0.05)$. A significant difference was found between the experiment and control group balance posttest values. It was observed that the balance score posttest value of the experimental group students was lower than the control group. The positive feature of the balance in the experimental group and the number of errors decreased $(\mathrm{U}=3224.500 ; \mathrm{p}<0.05)$.

Table-3: Experimental and Control group students' body weight and balance scores compared to the pre - posttest values.

\begin{tabular}{|c|c|c|c|c|c|}
\hline Variables & Group & Line Average & Line Total & $\mathbf{Z}$ & $p$ \\
\hline \multirow{4}{*}{$\begin{array}{c}\text { Body Weight } \\
\text { Pre Test-Post Test }\end{array}$} & \multirow[t]{2}{*}{ Experimental } & 28.94 & 492.00 & \multirow[t]{2}{*}{-2.391} & \multirow[t]{2}{*}{$0.017 *$} \\
\hline & & 27.58 & 1048.00 & & \\
\hline & \multirow[t]{2}{*}{ Control } & 17.88 & 214.50 & \multirow[t]{2}{*}{-1.734} & \multirow[t]{2}{*}{0.083} \\
\hline & & 18.07 & 415.50 & & \\
\hline \multirow{4}{*}{$\begin{array}{c}\text { Balance } \\
\text { Pre Test-Post Test }\end{array}$} & \multirow[t]{2}{*}{ Experimental } & 41.65 & 2915.50 & \multirow[t]{2}{*}{-7.214} & \multirow[t]{2}{*}{$0.000 *$} \\
\hline & & 12.50 & 87.50 & & \\
\hline & \multirow[t]{2}{*}{ Control } & 29.98 & 779.50 & \multirow[t]{2}{*}{-1.106} & \multirow[t]{2}{*}{0.269} \\
\hline & & 21.86 & 546.50 & & \\
\hline
\end{tabular}


As seen in Table 3 the body weight of the participants in the experimental group participating in the dance study was statistically significant. While an increase was observed $(Z=-2.391 ; p<0.05)$. Balance scores were found to decrease significantly $(Z=-7.214$; $\mathrm{p}<0.05)$. The decrease in balance scores of the experimental group has shown that the number of errors in the balance decreases. Therefore the balance feature related to dance work has also improved positively. In the control group no significant difference was found in body weight $(Z=-1.734 ; \mathrm{p}>0.05)$ and balance scores $(Z=-1.106 ; p>0.05)$.

Table-4: Comparison of $\mathrm{d} 2$ attention test pretest and posttest values of experiment and control group students

\begin{tabular}{|c|c|c|c|c|c|c|}
\hline Variables & & Group & Line Average & Line Total & $\mathbf{U}$ & $p$ \\
\hline \multirow[t]{4}{*}{ Attention Total Score } & \multirow[t]{2}{*}{ Pre Test } & Experiment & 107.02 & 10701.50 & \multirow[t]{2}{*}{4348.500} & \multirow[t]{2}{*}{0.111} \\
\hline & & Control & 93.98 & 9398.50 & & \\
\hline & \multirow[t]{2}{*}{ Post Test } & Experiment & 119.32 & 11931.50 & \multirow[t]{2}{*}{3118.500} & \multirow[t]{2}{*}{$0.000^{*}$} \\
\hline & & Control & 81.68 & 8168.50 & & \\
\hline \multirow[t]{4}{*}{ Error1 } & \multirow[t]{2}{*}{ Pre Test } & Experiment & 96.76 & 9675.50 & \multirow[t]{2}{*}{4625.500} & \multirow[t]{2}{*}{0.360} \\
\hline & & Control & 104.24 & 10424.50 & & \\
\hline & \multirow[t]{2}{*}{ Post Test } & Experiment & 98.06 & 9806.50 & \multirow[t]{2}{*}{4756.500} & \multirow[t]{2}{*}{0.552} \\
\hline & & Control & 102.94 & 10293.50 & & \\
\hline \multirow[t]{4}{*}{ Error2 } & \multirow[t]{2}{*}{ Pre Test } & Experiment & 96.00 & 9599.50 & \multirow[t]{2}{*}{4549.500} & \multirow[t]{2}{*}{0.270} \\
\hline & & Control & 105.00 & 10500.50 & & \\
\hline & \multirow[t]{2}{*}{ Post Test } & Experiment & 89.16 & 8915.50 & \multirow[t]{2}{*}{3865.500} & \multirow[t]{2}{*}{$0.005^{*}$} \\
\hline & & Control & 111.84 & 11184.50 & & \\
\hline \multirow[t]{4}{*}{ Concentration } & \multirow[t]{2}{*}{ Pre Test } & Experiment & 105.70 & 10570.50 & \multirow[t]{2}{*}{4479.500} & \multirow[t]{2}{*}{0.203} \\
\hline & & Control & 95.30 & 9529.50 & & \\
\hline & \multirow[t]{2}{*}{ Post Test } & Experiment & 117.08 & 11707.50 & \multirow[t]{2}{*}{3342.500} & \multirow[t]{2}{*}{$0.000^{*}$} \\
\hline & & Control & 83.92 & 8392.50 & & \\
\hline
\end{tabular}

As seen in Table 4. Experimental group pretest total attention score $(\mathrm{U}=4348.500)$. Error1 $(\mathrm{U}=$ 4625.500). Error2 $(\mathrm{U}=4549.500)$ and concentration scores $(U=4479.500)$ and the control group did not differ significantly ( $\mathrm{p}>0.05$ ). A significant difference was found in the total attention score. Error2 score and concentration posttest values of the experimental group and control group students. Total attention $(\mathrm{U}=$ $3118.500)$ and concentration scores $(\mathrm{U}=3342.500)$ measured in the posttest of the experimental group were significantly higher than the control group. ( $p<0.05)$. Error2 score was higher in the control group compared to the experimental group ( $\mathrm{U}=3865.500 ; \mathrm{p}<0.05$ ). Posttest Error1 scores were not found to be significantly different between experimental and control groups ( $\mathrm{U}=$ $4756.500 ; \mathrm{p}>0.05)$. There was a positive change in the attention and concentration posttest values of the students who participated in the exercise.

Table-5: Comparison of d2 attention test pretest and posttest values of experiment and control group students

\begin{tabular}{|c|c|c|c|c|c|}
\hline Variables & Groups & Line Average & Line Total & $\mathbf{Z}$ & $p$ \\
\hline \multirow{4}{*}{$\begin{array}{l}\text { Total Attention score } \\
\text { Pre Test-Post Test }\end{array}$} & \multirow[t]{2}{*}{ Experiment } & 48.09 & 817.50 & \multirow[t]{2}{*}{-5.871} & \multirow[t]{2}{*}{$0.000 *$} \\
\hline & & 50.99 & 4232.50 & & \\
\hline & \multirow[t]{2}{*}{ Control } & 48.24 & 2315.50 & \multirow[t]{2}{*}{-0.720} & \multirow[t]{2}{*}{0.471} \\
\hline & & 52.59 & 2734.50 & & \\
\hline \multirow{4}{*}{$\begin{array}{c}\text { Error1 } \\
\text { Pre Test-Post Test }\end{array}$} & \multirow[t]{2}{*}{ Experiment } & 49.11 & 3094.00 & \multirow[t]{2}{*}{-2.161} & \multirow[t]{2}{*}{$0.031 *$} \\
\hline & & 51.56 & 1856.00 & & \\
\hline & \multirow[t]{2}{*}{ Control } & 52.63 & 3052.50 & \multirow[t]{2}{*}{-1.814} & \multirow[t]{2}{*}{0.070} \\
\hline & & 47.56 & 1997.50 & & \\
\hline \multirow{4}{*}{$\begin{array}{c}\text { Error2 } \\
\text { Pre Test-Post Test }\end{array}$} & \multirow[t]{2}{*}{ Experiment } & 46.45 & 2601.00 & \multirow[t]{2}{*}{-2.229} & \multirow[t]{2}{*}{$0.026 *$} \\
\hline & & 43.94 & 1494.00 & & \\
\hline & \multirow[t]{2}{*}{ Control } & 44.15 & 2031.00 & \multirow[t]{2}{*}{-0.421} & \multirow[t]{2}{*}{0.674} \\
\hline & & 48.85 & 2247.00 & & \\
\hline \multirow{4}{*}{$\begin{array}{c}\text { Concentration } \\
\text { Pre Test-Post test }\end{array}$} & \multirow[t]{2}{*}{ Experiment } & 44.38 & 1109.50 & \multirow[t]{2}{*}{-4.867} & \multirow[t]{2}{*}{$0.000 *$} \\
\hline & & 52.54 & 3940.50 & & \\
\hline & \multirow[t]{2}{*}{ Control } & 56.22 & 2024.00 & \multirow[t]{2}{*}{-1.423} & \multirow[t]{2}{*}{0.155} \\
\hline & & 45.60 & 2827.00 & & \\
\hline
\end{tabular}

As seen in Table 5 a significant difference was found in the total attention. Error1, error2 and concentration values of the students who performed dance exercise $(\mathrm{p}<0.05)$. There was no significant change in the control group $(Z=-5.871 ; p<0.05)$ in the control group. Where the total attention scores of the students in the experimental group showed a significant increase at the end of the dance study $(Z=0.720 ; p>$ $0.05)$. While a significant decrease was determined as a pretest $(Z=-2.161 ; p<0.05)$. It was found that the control group did not show statistically significant difference between the Error1 posttest scores $(Z=-$ $1.814 ; p>0.05)$. It was observed that the applied study significantly decreased the Error2 scores of the 
experimental group $(Z=2.229 ; \mathrm{p}<0.05)$ and did not cause a significant change in the control group $(\mathrm{Z}=-$ $0.421 ; p>0.05)$. Concentration scores increased in the experimental group $(Z=-4.867 ; \mathrm{p}<0.05)$. But no significant change was observed in the control group $(\mathrm{Z}$ $=-1.423 ; \mathrm{p}>0.05)$.

\section{DISCUSSION AND CONCLUSION}

A comparison of the body weight and balance scores of the experimental and control group students participating in the research is presented. As a result of comparison of pre-tests, it was determined that body weight and balance scores did not differ between experiment and control groups. As a result of comparing the post tests, it was found that the body weight did not differ significantly between the experimental and control groups similar to the pretest. A significant difference was found between the experiment and control group balance posttest values. It was observed that the balance score posttest value of the experimental group students was lower than the control group, the positive feature of the balance feature in the experimental group and the number of errors decreased (Table 2). In their study, Şimşek and Uzuner [34] concluded that "3-month Cha Cha training increases aerobic capacity depending on the duration of their engagement with dance sports. It was determined that the physical parameters of students who received sports education and those who received folklore training were similar. In University students participating in a 12 week folk dance study applied weekly, a decrease in resting heart rate, decrease in body weight, decrease in body fat percentage, increase in body mobility, increase in right hand and left hand grip strength, increase in leg strength, increase in anaerobic and aerobic power [35-36] found that there were significant differences between pre-test and posttest scores of body weight, BMI, flexibility, balance, concentration among the students doing dance exercises (the experimental group). There were no significant differences between pre-test and post-test scores of body weight, BMI, concentration among the students not doing dance exercises (the control group) but there were significant differences in flexibility and balances cores. A statistically significant increase was observed in the body weight of the participants in the experimental group participating in the dance study, while the balance scores were found to decrease significantly. The decrease in balance scores of the experimental group has shown that the number of errors in the balance decreases, therefore, the balance feature related to dance work has also improved positively. There was no significant difference in body weight and balance scores in the control group (Table 3). At the end of the three-month Latin American dance "cha cha" training for 18-25 years old. Men and women who have begun dancing and continued dancing for 5-9 years, the 3-month paired dance training applied, extended the fatigue rate, fatigue time and body in both men and women reduced the fat rate [37]. The problem solving skills of the students according to the rhythm education and whether or not to take dance lessons were examined in a study. It was determined that the students developed themselves in the rhythm education and dance lessons with the performances they prepared, increasing their confidence in them, improving their creativity and affecting their problem solving skills positively [38]. In the study of Alp [39] with university students, an increase was observed in the rhythm feelings of the students after playing folk dances and it was determined that there was no significant difference. Group students' total attention score, error2 score and concentration were significant in post-test values. A significant difference has been found. It was determined that the total attention and concentration scores of the experimental group measured in the posttest were significantly higher than the control group, while the Error2 score was higher in the control group compared to the experimental group. It was determined that posttest Error1scores were not significantly different between experiment and control groups. A positive change was observed in the attention, error, and concentration post-test values of the students who participated in the dance exercise (Table 4). Akandere et al. [40] found that the problem-solving skills of the subjects who participated in research differed at the beginning and the end of dance exercise. Kilıç, [41] found that games involving music activities give students the ability to listen, recognize, memory, rhythm patterns, and coordination. Erdal, [42] concluded that the use of music during the exercise by athletes positively affects athletes in self-confidence, self-worth, focusing on the subject, and more exercise. Total attention, Error1, Error 2 and concentration. There was a significant difference in the total attention scores of the students in the experimental group after the dance study, no significant change was detected in the control group. While there was a statistically significant decrease in the Error1 scores of the experimental group between the pre-posttest, it was found that the Error1 scores of the control test-group did not differ significantly. It was observed that the applied study significantly decreased the Error2 scores of the experimental group and did not cause a significant change in the control group. Concentration scores increased in the experimental group, but no significant change was observed in the control group (Table 5). Akman [43], found that dancers are more flexible than sedentary individuals and have a better vertical leap (explosive force). In Ateş [44], study, it was determined that the personality traits of individuals engaged in dance sports differ significantly from the personality traits of individuals engaged in team sports and individual sports. In a study where the effect of game education on the attention and concentration level of sedentary children and hand-eye coordination, it was found that educational games and dart games had a high level of positive effects on students' attention and concentration and hand-eye coordination levels [45]. It was found that the hopelessness levels of university 
students who danced decreased [46]. These research findings support our study. As a result, the body weight of the students participating in the research was determined by the pretest and posttest values. As a result, no significant difference was found between the experimental and control groups of the body weight pretest and posttest values of the students participating in the research. There was no significant difference in the test value of balance between experiment and control groups. However, a significant difference was found between the experimental and control groups in the balance posttest value. The decrease in the balance posttest value of the experimental group students shows that the balance feature in the experimental group showed positive development and the number of errors decreased. A statistically significant increase was observed in the body weight of the participants in the experimental group participating in the dance study, while the balance scores were found to decrease significantly. There was no significant difference in body weight and balance scores in the control group. A significant difference was found in the total attention score, error2 score and concentration post-test values of the experimental group and control group students. A positive change in the attention, error, and concentration post-test values of the students participating in the dance study was detected. A significant difference was found in the total attention, Error1, Error2 and concentration values of the students who performed dance exercises. The total attention scores of the students in the experimental group showed a significant increase at the end of the dance study, and there was no significant change in the control group. The dance study applied significantly decreased the Error1 and Error2 scores of the experimental group, meanwhile it was not seen to cause change in the control group. Concentration scores increased in the experimental group, but no significant change was observed in the control group. It has been determined that dance work positively affects balance and attention.

\section{REFERENCES}

1. Caglar, E., \& Koruç, Z. (2006). Reliability and validity of $\mathrm{d} 2$ test of attention for athletes. Hacettepe Journal of Sport Sciences, 17(2), 58-80.

2. Brickenkamp, R. (1981). d2 AufmerksamkeitBelastungs Test, Handanweisung. Goettingen: Hogrefe.

3. Tokinan, B. O., \& Bilen, S. (2010). Development of a questionnaire for the evaluation of selfefficacy related to body language and dance. Ankara University, Journal of Faculty of Educational Sciences, 43(2), 75-88.

4. Meb. (2006). 12th Grade Rhythm Education and Dance Teaching Program, Ankara.

5. Hugel, F., Cadopi, M., Kohler, F., \& Perrin, P. (1999). Postural control of ballet dancers: a specific use of visual input for artistic purposes. International Journal Sports Medicine, 20, 86-92.
6. Cantekin, D. (2011). Movement analises of term in dance. Master Thesis, Institute of Social Sciences, Sakarya: Sakarya University.

7. Esen, A. (2012). Effect of Dance Training on Joint Position Perception Levels. Master Thesis, Institute of Healty Sciences, İzmir, Ege University.

8. Aldemir, G.Y. (2010). The effect of drama and dance education on motor characteristics development of children aged 10-14. Master Thesis, Institute of Healty Science, Istanbul: Marmara University.

9. Daşdan, G. (2013). The effect on the self-efficacy perceive related to body language and dance of physical self-perceive. Master Thesis, Institute of Education Sciences, Mersin, Mersin University.

10. Adame, D.D., Radell, S.A., Johnson, T.C. \& Cole, S.P. (1991). Physical fitness, body image, and locus of control in college women dancers and no dancers. Perceptual and Motor Skills, 72, 91-95.

11. Hui, E., Chui, B.T., \& Woo, J. (2009). Effects of dance on physical and psychological well-being in older persons. Archives of Gerontology and Geriatrics, 49, 45-50.

12. Murcia, J.A.M., Noguera, F.C., Coll, D.G., Gimeno, E.C., \& Pérez, L.M.R. (2009). Flow disposicional en salvamento deportivo: una aproximacion desde la teoria de la autodeterminacion. Revista de Psicología del Deporte, 18, 23-35.

13. Kierr, S. (2011). Is dance/movement therapy relevant to the process of achieving a healthy sexuality? American Journal of Dance Therapy, 33(1), 42-56.

14. Horak, F.B., \& Macpherson, J.M. (2011). "Postural orientation and balance" Comprehensive Physiology, \{http://www.comprehensivephysiology.com/Wiley CDA/\}, 15 November 2019.

15. Deliagina, T.G., Zelenin, P.V., Beloozerova, I.N., \& Orlovsky, G.N. (2007). Nervous mechanisms controlling body posture. Physiology \& Behavior, 92(1), 148-154.

16. Daneshjoo, A., Mokhtar, A.H., Rahnama, N., \& Yusof, A. (2012). The effects of comprehensive warm-up programs on proprioception, static and dynamic balance on male soccer players. Plos One, 7(12), e51568.

17. Kocaaga, T. (2014). The effects of exerciseinduced muscle damage on balance performance. Master Thesis, Institute of Healty Sciences, Bolu, Abant İzzet Baysal University.

18. Dogan, O. (2005). Sports Psychology. Nobel publication distribution.

19. Karahan, I. (2008). Having attention strategies in teaching process of working teachers at primary schools. Master Thesis, Institute of Social Sciences, Istanbul, Yeditepe University.

20. Ozbay, Y. (2003). Development and learning psychology (4th Edition). Academy Publishing House. 
21. Ünal, S., \& Ada, S. (2001). Introduction to teaching profession. Istanbul: Marmara University, Technical Education Faculty Publications.

22. Karip, E. (2003). Classroom Management. Ankara: Pegem Publishing, 11-28.

23. Kaymak, S. (2003). Improving the concentration skill of children attending the second and third classes of a primary school, PhD Thesis, Institute of Social Sciences, Ankara, and Ankara University.

24. Ozturk, O. (2008). Research about the effect of the family attitude in solving the problems of hyperactive children (7-12 ages) and their academical success. Master Thesis, PhD Thesis, Institute of Social Sciences, Istanbul, Maltepe Üniversity.

25. Mesulam, M.M. (2004). Attention networks, confusional conditions and neglect syndromes: principles of behavioral and cognitive neurology. Yelkovan Publications, Translation: Ed. H. Gürvit, Istanbul.

26. Johnson, R.E., Kirkendall, D.R., \& Gruber, J.J. (1987). Measurement and evaluation for PE. USA: Human Kinetics Publishers.

27. Atilgan, E.O. (2003). Evaluation of the effect of rhythm education on acquirıng complex gymnastics skills, PhD Thesis, Institute of Healty Science, Istanbul: Marmara University.

28. Brickenkamp, R. (1966). Die stabilitat des Aufmerksamkeits-Belastungs-Tests (Test d2) über langere Zeitabschnitte.

29. Spreen, O., \& Strauss, E. (1998). A Compendium of Neuropsychological Tests (2nd ed.). New York: Oxford University Press.

30. Brickenkamp, R., Zillmer, E. (1998). The d2 Test of Attention. Seattle: Hogrefe \& Huber Publishers.

31. Oswald, W.D., \& Hagen, B. (1997). Test d2Aufmerksamkeits-Belastungs-Test. Zeitschrift fuer Differentielle und Diagnostische Psychologie, 18(1-2), 87-89.

32. Yayci, L. (2007). Testing the effectiveness of a programme based on improving selective and focused attention skills with 4th grade students in elementary education. PhD Thesis, Istanbul:, Institute of Education Sciences, Istanbul, Marmara University.

33. Toker, M.Z. (1990). Adaptation study of d2 attention test, V. National Psychology Congress. Izmir: Psychology-Seminar Journal Special Issue 8, 627-635.

34. Simsek, D., \& Uzuner, K. (2011). The Effects of cha cha dance training on cardio-respiratory parameters. Ankara University, Journal of Physical Education and Sport Science, 8(4), 137-142.

35. Kay, H.C. (2008). A study of the effects of 12week regular folk dance education on some physical and physiological parameters of students (example from county of Afyonkarahisar), Master
Thesis, Institute of Healty Sciences, Afyonkarahisar, Afyon Kocatepe University.

36. Bastug, G. (2018). Examination of body composition, flexibility, balance, and concentration related to dance exercise, Asian Journal of Education and Training, 4(3), 210-215.

37. Yenigelen, D. (2006). Cardio-respiratory effects of 3-month Latin American cha cha dance training on 18-25 ages men and women of 5-9 years dancing dancers and beginners of dance training groups., Master Thesis, Institute of Healty Sciences, Eskisehir, Eskisehir Osmangazi University.

38. Kuru, E. (2009). Analysis of problem solving skills of school of physical education and sports students taking or not taking rhythm training and dance lesson in terms of various variables. Gazi University, Journal of Gazi Educational Faculty, 29(2), 441-445.

39. Alp, M.Z. (2010). Effect of folk dances on rhythm sense, body composition and development of reaction time. Master Thesis, Institute of Social Sciences, Sakarya: Sakarya University.

40. Akandere, M.; Bastug, G.; Demir, H., \& Tasgin, Ö. (2010). Examining problem-solving skills of the students practicing dance for 12 weeks in terms of gender variable. Ovidius University Annals, Series Physical Education and Sport / Science, Movement and Health, 10(2), 635-638.

41. Kiliç, I. (2012). Preschool Music EducationPractice Examples with Activities. Pegem Academia Publishing, Ankara.

42. Erdal, G. (2005). Dalcroze Method and Usage of Music Teaching Methods. Erciyes University GSF Music Symposium Declaration, Kayseri/Turkey.

43. Akman, M. (2007). The examination of knee proprioception and joint position sense among black sea folk dances performers. Master Thesis, Institute of Healty Science, Istanbul: Marmara University.

44. Ateş, F. (2009). Comparation of personality characteristic of people engaged in dance sport with people engaged in other sport events (Atletics, Basketball, Volleyball, and Tennis Etc.) Master Thesis, Institute of Healty Science, İzmir: Ege University.

45. Orhan, S. (2018). The effects of game education on attention and concentration levels and hand-eye coordination of the sedentary children., Master Thesis, Elazıg, Firat Üniversity, Institute of Healty Sciences.

46. Bastug, G., \& Demir, B. (2010). Examination of the hopelessness levels of university students who are studying dance for twelve weeks according to gender variable. 3. Women as an international science category; Women's Symposium on Literature, Language, Culture and Art studies, Selcuk University, Dilek Sabancı State Conservatory, 28-30 April, Turkey. 